\title{
Fertilizer effect and a model for forecasting yields
}

\author{
LAURI KETTUNEN and TUOMO HEIKKILÄ \\ Agricultural Economics Research Institute, Rukkila, 00001 Helsinki 100
}

\author{
ANTTI JAAKKOLA \\ Agricultural Research Centre, Institute of Agricultural Chemistry and Pbysics, \\ 31600 Jokioinen
}

Abstract. A simulation model for forecasting the development of crop yields is built in the article. A parabolic function is applied to represent the fertilizer effect on yields. The biological-technological development is taken into account by including the time factor into the yield function. The parameters of the functions are estimated from the data obtained from field experiments.

The economic optimum determines the use of fertilizers which, in turn, is needed to calculate final forecasts of yields for each year. The user of the model may freely select the growth rate of the fertilizer price. The rise in production costs is compensated to the farmers by raising producer prices accordingly.

\section{Introduction}

Many factors affect the evolution of crop yields. Plant breeding, new varieties, the use of fertilizers and other chemicals increases, the cultivation technology improves, etc. As a result of all these factors per hectare yields have risen by $1-2$ per cent per year. Some forecasts of future development indicate that the development will continue as hitherto. These forecasts are, however, based on the assumption of a normal or uniform development, e.g. that the use of fertilizers will grow.

The rise of the price of energy has upset the law of continuity mentioned above. It is possible that the rise in the price of fertilizers, which need a lot of energy, will lower the use of fertilizers so that the yields will fall too. The situation is confused in the growing economy: development seems to turn backwards. So far, however, this is only speculation, of which there is no evidence as yet.

In this article a simulation model is presented which can be applied in studying the effect of some factors on yields on the basis of various assumptions. The yield model is a part of the Finnish food and agriculture model, which is intended for forecasting the agricultural development (KETTUNEN 1980). Fertilizers are only one factor affecting agricultural production, even though it is one of the most important factors. General economic and technological development does, unavoidably, also effect agriculture. We should be prepared for the challenges of the future 
but we do not know the future or the line of development. Hopefully, simulation methods will shed some light on the issue. They produce alternative development lines based on different assumptions or scenarios. What is the true or the most probable development cannot be ascertained by this method, but it is hoped to give hints of how catastrophes can be avoided and perhaps also of how to bring about the best development.

The yield model developed in this study generates yield estimates for the whole country. There are, however, no statistics suitable for the estimation of the parameters of the model. The problem has been solved by applying statistical information from field experiments. The article deals first with the results of these experiments and applies them to estimate the relationship between yield and fertilizer use (ceteris paribus). Thereafter a more general yield function is derived. - A more comprehensive report of the research results is published in Finnish by HEIKKILÄ (1980).

\section{Yield function}

The yield function is a typical production function where the quantity of yield depends on the amounts of different inputs like fertilizers, pesticides, labour, etc. In this connection we consider the relationship

$$
\begin{aligned}
& \text { 2.1. } \mathrm{Y}=\mathrm{f}(\mathrm{N}) \\
& \text { where } \mathrm{Y}=\text { yield level, } \mathrm{kg} \text { per hectare } \\
& \mathrm{N}=\text { use of fertilizer (nitrogen), kg per hectare }
\end{aligned}
$$

It is possible to estimate this type of a function where there is only one explanatory variable by using the statistics from field experiments, where the plots placed side by side are fertilized by varying amounts of nitrogen. Thus it is possible to eliminate the effect of other factors like soil and weather almost completely. Nitrogen alone represents usually the variable fertilizer since it is most usually the limiting factor. Potassium $(\mathrm{K})$ and phosphorus $(\mathrm{P})$ are available in sufficient amounts for all experimental plots.

What is the form of the function? Usually diminishing marginal response is assumed. There are several functions which fulfill this requirement. The fertilizer effect may even become negative. This additional condition is also fulfilled by several functions. The parabolic function

\section{2. $\mathrm{Y}=\mathrm{a}+\mathrm{bN}+\mathrm{cN}^{2}$}

has often been applied with great success to describe the fertilizer effect (see e.g. HEADY and DILLON 1961, IHAMUOTILA 1970 and COOKE 1972). The graphic inspection of the results of field experiments favours this model, and so it was also chosen for application in this study.

The function 2.2. depicts the yield function ceteris paribus. When it is applied for forecasting, other factors such as new varieties, improved technology, increased use of pesticides, drainages, etc. have to be taken into account. Each of them could be, in principle, included in the yield function. However, in practice this might turn out to be difficult or impossible to apply since, at first, their development should be 
forecasted before the main model could be used. Therefore, in this study, other factors have been represented by a single variable, time $t$ :

\section{3. $\mathrm{Y}=\mathrm{f}(\mathrm{N}, \mathrm{t})$}

This solution means that other factors are assumed to affect the yields autonomously through time. The pace of development can certainly be varied if necessary.

The function 2.3. has to be specified. Is the effect of other factors (or of $t$ ) linear, accelerating or diminishing, and does it possibly reach a maximum? In this study it is assumed that the effect of other factors - in short that of biological - technological development - is growing at a diminishing pace which can be presented by the following function (HEIKKILÄ 1980, KETTUNEN 1980):

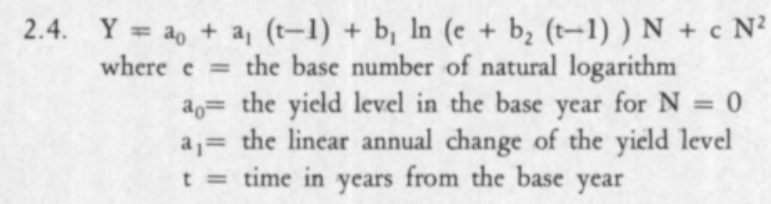

The function 2.4. looks a little complicated. Figure 1 illustrates the model. In the base year the yield function is like the model 2.2. (the lowest curve, $t-1$ ). The biological-technological development moves the curve upwards and to the right. When the model was developed much time was devoted to whether the curve moves only upwards when the maximum yield level would be obtained by the same amount of fertilizer, or whether it also shifts to the right, when a greater amount of fertilization is needed for obtaining the maximum. The latter alternative was accepted.

The form of the function implies also that the economic optimum of the use of fertilizers likewise shifts to the right.

This is an essential feature of the model as will be seen later. It is possible to depict the linear development through time by the model 2.4 . by making $b_{1}=c=0$ :

\section{5. $\mathrm{Y}=\mathrm{a}_{0}+\mathrm{a}_{1}(\mathrm{t}-1)$}

The model is thus very flexible for simulation. There are no fertilizer experiments for some products and so we have to apply a linear function for forecasting. In some cases (like potatoes) the evolution of yields depends on other factors than

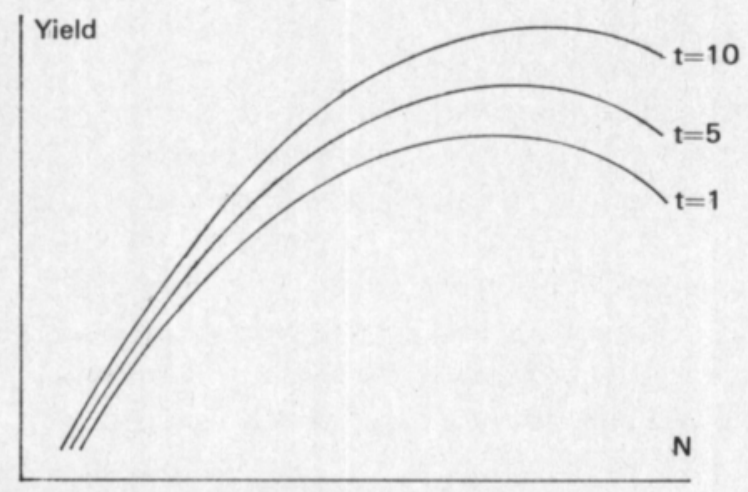

Figure 1. The yield function. 
fertilization, e.g. on the improvement of seeds. The use of fertilizers has to be omitted in these cases (fruits, potatoes, vegetables) and only the function 2.5. is applied.

\section{Data}

For estimation of the parameters of the function 2.4. the field experiments of the Agricultural Research Centre are mostly applied. Some results of experiments in Tikkurila, Jokioinen, some experimental stations and on permanent experimental fields were used for estimation. Similarly, fertilization experiments performed by Kemira Co. in co-operation with $4 \mathrm{H}$ clubs were applied (as is indicated by Appendix 1 where the experiment locations are given).

Field experiment results have been published in kilograms per hectare of storable yield (moisture 15 per cent for hay and grains, 9 per cent for oil seeds). However, research results of silage have been given in kilograms of dry matter per hectare.

The treatments in the experiments under study were given as compound NPK fertilizers. Phosphorus and potassium were assumed not to affect the yield because of sufficient soil reserves. There is evidence that nitrogen fertilizers mostly determine the yield level (MELA and HAAPALAINEN 1976, p. 7). Accordingly, the only explanatory variable has been the use of nitrogen, even though the potassium and phosphorus amounts have changed when compound fertilizers have been applied.

The use of fertilizer varied between 0 and $200 \mathrm{~kg}$ per ha of nitrogen for grains and oil seeds, between 0 and $600 \mathrm{~kg}$ per hectare of nitrogen for silage and between 0 and $135 \mathrm{~kg}$ per hectare of nitrogen for hay and 4 or 5 fertilizer levels were usually applied. However, in some cases only 3 fertilizer levels were used which is in fact too few for a meaningful function.

The experiments have continued in some cases for ten years. Yearly averages were used to estimate the parameters.

\section{Results of the estimation}

Fitting a parable into data where there are only few observations succeeds rather well. The parable goes always through 3 points, i.e. the fit is 100 per cent. These experiments were dealt with like the others even though the models are not statistically meaningful. The estimates are given in Appendix 1. The graphs of some estimated functions are given in Figure 2. For further discussion of estimated models, see HEIKKILÄ (1980).

Despite the few observations some conclusions may be drawn. Firstly, regional differences are great. Secondly, many of the functions indicate that the maximum yield is obtained by using $150-200 \mathrm{~kg}$ of nitrogen per hectare. Thirdly, the average use of nitrogen in the whole country, about $80 \mathrm{~kg}$ per ha, is much below the economic optimums given by the estimated functions.

Theoretically at least it is interesting to know how low the yields would fall if no fertilizer were available. The estimated functions give in some cases surprisingly high intercept values for $\mathrm{N}=0$. Field experiments are not, of course, very suitable for a conclusion covering the whole country but they are indicative to some extent. 




SPRING WHEAT

Tikkurila 1969-78

Kotkaniemi -"-

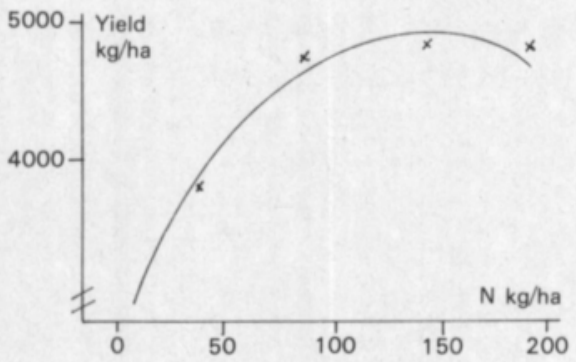

Oats

Kotkaniemi 1969-78

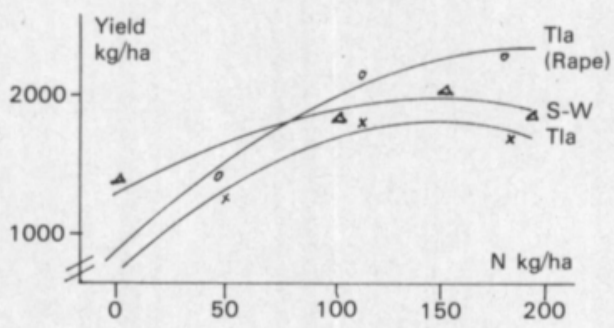

SPRING OILSEED TURNIP RAPE

Tikkurila 1977-78

S-W Finland 1975 and 77

SPRING OILSEED RAPE

Tikkurila 1977-78

Figure 2. The graphs of some estimated functions.

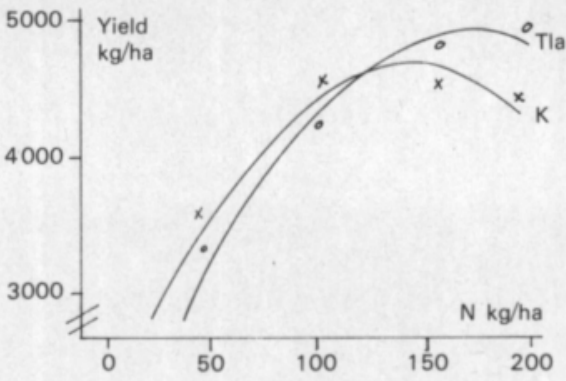

BARLEY

Tikkurila $1969-78$

Kotkaniemi 1969-78

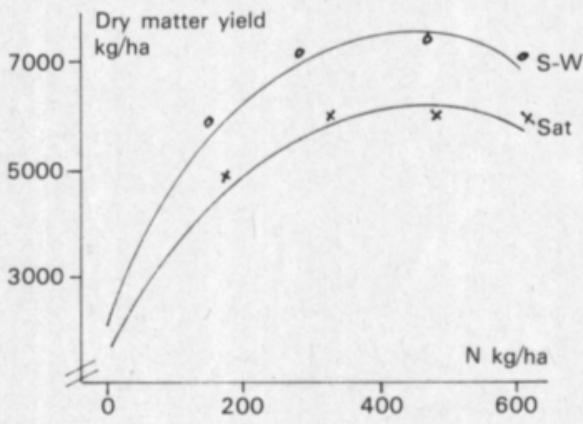

SILAGE

S-W Finland 1967-71

Satakunta 1966-71

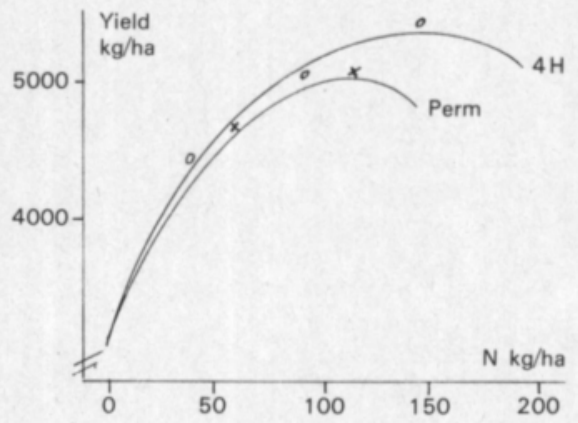

$4 \mathrm{H}$-Kemira Co.

$1977-78$

Permanent field experiments

$1966-75$ 
5. Application for forecasting yield for the whole country

In Chapter 2 the function 2.4. was derived which can be applied for long term forecasting. Field experiments give a function which is applicable for that particular region. For our purposes it should be generalized for the whole country. Field experiment functions are static, they do not contain any information as to the biological-technological development. Their yield level is also higher than that in the whole country. The forecasting model has, however, to generate predictions (or simulations) which start from the present level. The problem was solved by combining the general information of yields and fertilization with the results of field experiments.

To estimate the parameters it was assumed that the use of fertilizer in 1978 was optimal. The estimate of the coefficient $\mathrm{c}$ for bread grain was obtained by calculating the average of the c-coefficients for wheat of 10 year functions for Tikkurila and Kotkaniemi, and the coefficient $\mathrm{c}$ for feedstuffs from the corresponding experiments for barley. After that it is possible to estimate the parameters $a_{0}$ and $b_{1}$ in function

\section{1. $\mathrm{Y}=\mathrm{a}_{0}+\mathrm{b}_{1} \mathrm{~N}+\mathrm{c} \mathrm{N}^{2}$}

by applying the optimum condition and the base year values for prices and the yield (Y).

Subsequently the coefficients concerning the biological - technological development, $b_{2}$ and $a_{1}$ have to be estimated. Here we have had to apply conventional knowledge and common sense. We have assumed 8 per cent growth of yields in ten years, fertilization being constant, and calculated coefficients which meet this requirement. Other assumptions of the growth effect of biological-technological development would, of course, give different estimates and this it is possible to do but, unfortunately, it is not yet computerized so that it could be done easily.

This way the following yield function for bread grain was obtained:

5.2. $\mathrm{Y}=1702+5(\mathrm{t}-1)+18,16 \ln (\mathrm{e}+0,02072(\mathrm{t}-1)) \mathrm{N}-0,0744 \mathrm{~N}^{2}$

and for feedstuffs which include barley, oats, hay and silage measured in feed units:

5.3. $\mathrm{Y}=1135+5(\mathrm{t}-1)+25,74 \ln (\mathrm{e}+0,01413(\mathrm{t}-1)) \mathrm{N}-0,1258 \mathrm{~N}^{2}$

The models are applied for forecasting as follows. The model user may select the annual growth rate of fertilizer price. The rises in fertilization costs are compensated to the farmers by raising the producer prices accordingly (fertilization costs are about 10 per cent of the producer prices). The simulation model then calculates the optimum use of fertilizer and finally the yield level from the yield functions.

\section{Discussion of the forecasting model}

The readers as well as the authors of this paper may criticize the model derived. The first point is the assumption of the optimal use of fertilizers in the base year. The alternative assumption which was considered was that the fertilization is not optimal 
but would be approached in time. In that case we should have had to solve how far the whole country was from the optimum and at what pace the optimum would be approached, and the problem would not have been any easier to solve. In fact, it may be argued that the practical optimum is lower than the purely computational optimum. In addition, there are always farmers who use fertilizers less than the optimum. In any case, there will always be uncertainties which have to be accepted irrespective of the conclusion made. The principle of determining the optimal use of fertilizer is, however, a reliable and sound basis for long term forecasts. If better estimates of parameters are obtained later, they can be easily included into the model.

The models give the following forecasts. If price relations stay constant, the yield of bread grains will rise by about 0.8 per cent per year and it will be $3050 \mathrm{~kg}$ per ha in 1990 . The yield of feedstuffs will also grow by 0.8 per cent per year or to 2650 f.u. per ha by 1990 . The change of price relations has also an effect on yields. The doubling of the fertilizer price in ten years has, however, surprisingly little effect on the yield which would be only $70 \mathrm{~kg}$ per ha lower than if price relations remained constant, assuming, of course, that the rise of costs is compensated to the farmers.

Acknowledgement. This study is a part of the Finnish food and agriculture model project which has been financially supported by the Ministry of Agriculture and Forestry. The authors wish also to express their gratitude to the staff of the Agricultural Economics Research Institute for assistance in preparing this paper. We especially would like to thank $\mathrm{Mr}$. Seppo Pursiainen for building the computer programme for the model.

\section{References}

COOKE, G. 1972. Fertilizing for Maximum Yield. 296 p. London.

HEADY, E. \& DILLON, J. 1961. Agricultural Production Functions. 667 p. Ames.

HEIKKILÄ, T. 1980. Typpilannoitteiden taloudellisesta käytöstä koetulosten perusteella. Maatal. tal. tutk.lait. Tied. 70: 1-45.

IHAMUOTILA, R. 1970. The Effect of Increasing Nitrogen Fertilization on the Economic Result in Corn Production. Maatal. tal. tutk.lait. Julk. 21. 28 p. Helsinki.

KETTUNEN, L. 1980. Food and Agriculture Model for Finland. J. Scient. Agric. Soc. Finl. 52: 441-455.

MELA, T. \& HAAPALAINEN, M. 1976. Hehtaarisatojen ja tärkeimpien satoon vaikuttavien tekijöiden kehitys vuosina 1956-75 ja ennuste vuoteen 1985. Maatal. tutk.keskus, Kasvinvilj.lait. Tied. 4: 1-60.

Ms received November $11,1980$. 


\section{Lannoitusvaikutus ja hehtaarisatojen ennustemalli}

\section{Lauri Kettunen ja Tuomo Heikkilä}

Maatalouden taloudellinen tutkimuslaitos, Rukkila, 00001 Helsinki 100

\section{Antti Jaakkola}

Maatalouden tutkimuskeskuksen maanviljelyskemian ja -fysiikan laitos, 31600 Jokioinen

Eri kasvien satotason ennustamiseksi on tutkimuksessa aluksi estimoitu lannoituskokeista saadun aineiston avulla satotason ja typpilannoituksen välinen riippuvuus. Satotasofunktiona on käytetty parabelifunktiota $\mathrm{Y}=\mathrm{a}$ $+\mathrm{bN}+\mathrm{cN}^{2}$, jossa $\mathrm{Y}=$ sato $\mathrm{kg} / \mathrm{ha}$ ja $\mathrm{N}=$ typen käyttö $\mathrm{kg} / \mathrm{ha}$. Tilastoaineistoa oli käytettävissä vuosilta 1970-78 usealta eri koeasemalta ja paikkakunnalta.

Satotasofunktion parametrien estimointia vaikeutti lannoituskokeissa kāytettyjen lannoitustasojen vāhäisyys: Se oli tavallisesti vain 3 :sta 5 :een. Tällöin funktion maksimin määrittäminen on useimmiten vaikeaa, joskin havaintojen perusteella muutamissa kokeissa pāästiin lähelle maksimia tai jopa maksimiin saakka.

Estimoituja funktioita oli suuri märä ja tulokset poikkeavat samankin kasvin osalta huomattavasti toisistaan paikkakunnasta ja ajankohdasta riippuen. Kokeet näyttävät osoittavan, että satotaso saavuttaa maksimin typen käytön ollessa $150-200 \mathrm{~kg} / \mathrm{ha}$, joskin tämän johtopäätöksen tekeminen ei ole yksikäsitteinen. Taloudellisesti optimaalinen lannoitustaso jää tietenkin maksimia alemmas.

Pitkän aikavälin ennusteita varten on lannoitustasofunktioon liitetty aikatekijä korvaamaan biologis-teknisen kehityksen vaikutusta. Tämän vaikutuksen on oletettu hidastuvan ajan kuluessa. Perusmallissa sen oletetaan nostavan satotasoa vajaa $1 \%$ vuodessa.

Lannoitteiden käytön määräytymisen oletetaan tapahtuvan lannoitteiden taloudellisesti optimaalisen käytön perusteella. Simulointimallissa lannoitteiden hintojen muutosvauhtia saa vaihdella vapaasti. Hintojen nousu kompensoidaan mallissa kokonaan viljelijöille, joskin lisäksi on mahdollista käyttää erillistä lannoiteveroa, jota ei kompensoida. 
Appendix 1. The estimates of regression coefficients $(a, b, c)^{1}$ of equation $\mathrm{Y}=\mathrm{a}+\mathrm{bN}+\mathrm{cN}^{2}(\mathrm{Y}=$ yield, $\mathrm{kg}$ /ha, $\mathrm{N}=$ application of fertilizer nitrogen, $\mathrm{kg} / \mathrm{ha})$ and the coefficients of determination $\left(\mathrm{R}^{2}\right)$.

\begin{tabular}{|c|c|c|c|c|c|}
\hline & & a & b & c & $\mathrm{R}^{2}$ \\
\hline \multicolumn{6}{|l|}{ RYE } \\
\hline \multicolumn{6}{|l|}{ Satakunta } \\
\hline experimental station ... & $1974-77$ & 2603 & $11.21^{* * *}$ & $-0.0243^{* \cdots *}$ & 0.999 \\
\hline \multicolumn{6}{|l|}{ S. W. Finland } \\
\hline experimental station & $1975-77$ & 2086 & $12.34^{* * *}$ & $-0.0171^{*}$ & 0.999 \\
\hline \multicolumn{6}{|l|}{ Kymenlaakso } \\
\hline experimental station & $"$ & 2590 & $7.47^{* * *}$ & $-0.0201^{* *}$ & 0.994 \\
\hline Total $\ldots \ldots \ldots \ldots$. & $"$ & 2438 & $11.02^{* *}$ & $-0.0255^{*}$ & 0.997 \\
\hline \multicolumn{6}{|l|}{ SPRING WHEAT } \\
\hline Kotkaniemi...$\ldots \ldots$ & $1969-78$ & 1903 & $26.18^{* * *}$ & $-0.0678^{* * *}$ & 0.999 \\
\hline Tikkurila .......... & $"$ & 1654 & $28.91^{* * *}$ & $-0.0810^{* * *}$ & 0.997 \\
\hline ..... & $1969-71$ & 1713 & $31.67^{* * * *}$ & $-0.0745^{* *}$ & 0.999 \\
\hline Jokioinen & $1972-75$ & 1957 & $13.33^{* *}$ & $-0.0477^{* *}$ & 0.972 \\
\hline \multicolumn{6}{|l|}{ S. W. Finland } \\
\hline experimental station & $1969-71$ & 1957 & $11.15^{*}$ & -0.0265 & 0.991 \\
\hline \multicolumn{6}{|l|}{ Kymenlaakso } \\
\hline experimental station & $"$ & 1116 & $9.77^{*}$ & -0.0280 & 0.968 \\
\hline \multicolumn{6}{|l|}{ BARLEY } \\
\hline Kotkaniemi ..... & $1969-78$ & 1908 & $39.02^{* * * *}$ & $-0.1331^{* *}$ & 0.995 \\
\hline Tikkurila ........ & $"$ & 1358 & $41.89^{* * * *}$ & $-0.1185^{* *}$ & 0.994 \\
\hline$\ldots \ldots$ & $1969-71$ & 1610 & $48.40^{* * * *}$ & $-0.1295^{* *}$ & 0.999 \\
\hline Jokioinen $\ldots \ldots \ldots \ldots$ & $1972-75$ & 2259 & $27.99^{* *}$ & $-0.0966^{* *}$ & 0.974 \\
\hline \multicolumn{6}{|l|}{ Permanent experimental } \\
\hline fields $\ldots \ldots \ldots \ldots \ldots$ & $1966-75$ & 2136 & 12.17 & -0.0288 & 0.999 \\
\hline \multicolumn{6}{|l|}{ S. W. Finland } \\
\hline experimental station & $1969-71$ & 2899 & $21.48^{* *}$ & $-0.0655^{*}$ & 0.996 \\
\hline \multicolumn{6}{|l|}{ Kymenlaakso } \\
\hline experimental station & $"$ & 1712 & $25.13^{* * *}$ & $-0.0790^{* * *}$ & 0.999 \\
\hline
\end{tabular}


Appendix 1. Continued.

\begin{tabular}{|c|c|c|c|c|c|}
\hline & & a & b & c & $\mathrm{R}^{2}$ \\
\hline \multicolumn{6}{|l|}{ OATS } \\
\hline Kotkaniemi ............. & $1969-78$ & 2517 & $33.96^{* * *}$ & $-0.1126^{* * *}$ & 0.999 \\
\hline Tikkurila .............. & $1969-71$ & 2480 & $41.06^{* * *}$ & $-0.1595^{* * *}$ & 0.999 \\
\hline Jokioinen $\ldots \ldots \ldots \ldots \ldots \ldots$ & $1972-75$ & 3138 & $16.97^{* *}$ & $-0.0634^{*}$ & 0.950 \\
\hline \multicolumn{6}{|l|}{ Permanent experimental } \\
\hline $\begin{array}{l}\text { fields } \ldots \ldots \ldots \ldots \ldots \ldots \ldots \\
\text { S. W. Finland }\end{array}$ & $1966-75$ & 2058 & 16.13 & -0.0786 & 0.999 \\
\hline $\begin{array}{l}\text { experimental station } \ldots \ldots \ldots \ldots \\
\text { Kymenlaakso }\end{array}$ & $1969-71$ & 2992 & $24.44^{* *}$ & $-0.0775^{*}$ & 0.996 \\
\hline $\begin{array}{l}\text { Kymenlaakso } \\
\text { experimental station } \ldots \ldots \ldots \ldots . . .\end{array}$ & $"$ & 2278 & $18.81^{*}$ & -0.0550 & 0.970 \\
\hline \multicolumn{6}{|c|}{ SPRING OILSEED TURNIP RAPE } \\
\hline $\begin{array}{l}\text { Tikkurila } \ldots \ldots \ldots \ldots \ldots \ldots \ldots \\
\text { S. W. Finland }\end{array}$ & $1977-78$ & 637 & $15.46^{* * *}$ & $-0.0502^{* *}$ & 0.999 \\
\hline experimental station $\ldots \ldots \ldots \ldots$ & 1975 ja 77 & 1247 & $9.82^{* *}$ & $-0.0324^{*}$ & 0.989 \\
\hline \multicolumn{6}{|l|}{ SPRING OILSEED RAPE } \\
\hline Tikkurila $\ldots \ldots \ldots \ldots \ldots \ldots$ & $1977-78$ & 760 & $17.37^{* *}$ & $-0.0471^{*}$ & 0.998 \\
\hline \multicolumn{6}{|l|}{ HAY } \\
\hline $\begin{array}{l}\text { 4H-Kemira Co. . . . . . . . . . . . } \\
\text { Permanent experimental }\end{array}$ & $1977-78$ & 3089 & $33.80^{* * * *}$ & $-0.1189^{* * *}$ & 0.999 \\
\hline fields $\ldots \ldots \ldots \ldots \ldots \ldots \ldots \ldots$ & $1966-75$ & 3045 & 37.84 & -0.1729 & 0.999 \\
\hline \multicolumn{6}{|l|}{ SILAGE } \\
\hline $\begin{array}{l}\text { experimental station } \ldots \ldots \ldots \ldots \ldots \\
\text { Satakunta }\end{array}$ & $1967-71$ & 2148 & $25.68^{* * *}$ & $-0.0290^{* * *}$ & 0.994 \\
\hline $\begin{array}{l}\text { experimental station } \ldots \ldots \ldots \ldots \ldots \\
\text { North Pohjanmaa }\end{array}$ & $1966-71$ & 1497 & $21.25^{* * *}$ & $-0.0232^{* * *}$ & 0.996 \\
\hline experimental station $\ldots \ldots \ldots \ldots$. & $1969-73$ & 3164 & $21.60^{* * *}$ & $-0.0341^{* * *}$ & 0.999 \\
\hline $\begin{array}{l}\text { Permanent experimental } \\
\text { fields } \ldots \ldots \ldots \ldots \ldots \ldots \ldots \ldots \ldots\end{array}$ & $1969-72$ & 3472 & 26.18 & -0.0422 & 0.999 \\
\hline
\end{tabular}

1) * Statistically significant at 95 per cent confidence level

** Statistically significant at 99 per cent confidence level

*** Statistically significant at 99.9 per cent confidence level 